\title{
BMJ Open Reactions to and explanations for the birth of a baby with albinism: a qualitative study in Busoga, Uganda
}

\author{
Julie Taylor (10 , ${ }^{1,2}$ C Bradbury-Jones, ${ }^{1}$ Peter Ogik, ${ }^{3}$ Fazira Kawuma, ${ }^{3}$ Jane Betts, ${ }^{4}$ \\ Patricia Lund ${ }^{5}$
}

To cite: Taylor J, BradburyJones C, Ogik P, et al. Reactions to and explanations for the birth of a baby with albinism: a qualitative study in Busoga, Uganda. BMJ Open 2021;11:e040992. doi:10.1136/ bmjopen-2020-040992

- Prepublication history for this paper is available online. To view these files, please visit the journal online (http://dx.doi org/10.1136/bmjopen-2020040992).

Received 27 May 2020 Revised 05 January 2021 Accepted 29 January 2021

Check for updates

(C) Author(s) (or their employer(s)) 2021. Re-use permitted under CC BY-NC. No commercial re-use. See rights and permissions. Published by BMJ.

${ }^{1}$ School of Nursing, College of Medical and Dental Sciences, University of Birmingham,

Birmingham, UK

${ }^{2}$ Birmingham Women's and

Children's Hospital NHS

Foundation Trust, Birmingham, UK

${ }^{3}$ Source of the Nile Union for Persons with Albinism, Jinja, Uganda

${ }^{4}$ Advantage Africa, Olney, UK

${ }^{5}$ School of Life Sciences, Coventry University, Coventry, UK

Correspondence to

Professor Julie Taylor;

j.taylor.1@bham.ac.uk

\section{ABSTRACT}

Objectives Babies born with the genetic condition albinism lack pigment in their hair, skin and eyes due to compromised melanin production. This leads to poor vision and the risk of early death due to skin cancer. In Uganda, one of the least developed countries in the world, their lack of pigmentation makes them very different in appearance within their communities. Local explanations of albinism include links to witchcraft and the supernatural. We aimed to explore reactions to the birth of a baby with albinism in Uganda.

Design Secondary analysis of birth stories derived from qualitative interviews and focus group discussions in sharing circles.

Setting Interviews took place in the Busoga subregion (kingdom) in the eastern part of Uganda.

Participants Seventy-three (73) participants took part in eight sharing circles $(n=56)$ and 17 individual interviews. Participants included people with albinism, parents of people with albinism and a range of other interested parties, including local leaders and teachers.

Results Reactions were generally those of shock and rejection, although cases of acceptance were also recorded. The varied explanations given to account for this unexpected event included accounts involving witchcraft, ghosts, animal familiars and religion, as well as genetics. In a framework surmising that someone must possess a dark skin to be intrinsically valued in African societies a baby with albinism does not fulfil this requirement of 'personhood'. The mother was often blamed for having produced some 'thing' that is not a proper person. Conclusions We argue that a biomedical explanation, although unlikely to displace other understandings, helps to establish a baby with albinism as a real person with a genetic difference, and hence fosters greater acceptance.

\section{INTRODUCTION}

Uganda in East-Central Africa is one of the least developed countries in the world ${ }^{1}$ with poor quality perinatal healthcare in rural areas. In Uganda a single midwife delivers $350-500$ babies a year. ${ }^{2}$ Although discouraged by the government, traditional birth attendants (TBAs), both trained and untrained, are still prevalent and attend around half of all births in rural parts of the country. ${ }^{3}$ Our study took place against this backdrop,

\section{Strengths and limitations of this study}

- This study provides hitherto unreported birth stories of people with albinism and the reactions and explanations given for such births, generating new knowledge in terms of understandings about albinism in Uganda.

- Data collection took place in rural and urban settings and was unusually large for a qualitative study, thus capturing a range of different experiences.

- Although the unique context of the Busoga subregion provides important insights, knowledge and practices are contextual and this limits generalisability.

- While participants appeared to speak freely and openly about their experiences, their ideas and opinions could have been influenced by the albinism society and its representatives.

exploring the birth stories of babies born with albinism.

\section{Oculocutaneous albinism in Africa}

Oculocutaneous albinism (OCA) is an inherited condition characterised by lack of melanin pigment which affects both genders and all populations. It is the predominant type of albinism in sub-Saharan Africa. The resulting hypo-pigmented (lighter) skin, hair and eyes makes individuals with albinism highly visible and extremely sensitive to the harmful effects of the sun, with an increased risk of skin cancers. ${ }^{4}$ In equatorial and tropical regions of Africa, they must take particular care to avoid sun exposure, placing additional restrictions on their daily lives. Albinism also impacts on visual acuity, with effects such as photophobia, strabismus and involuntary nystagmus leading to visual impairment. ${ }^{5}$ OCA has an estimated prevalence of between 1 in 1800-5000 in sub-Saharan Africa, ${ }^{6}$ but epidemiological studies are needed to confirm numbers and distribution.

Among populations such as in Uganda, the appearance of pale babies with albinism born to black parents is unusual, unexpected and 
can cause alarm among all those at the birth, including the mother and attendants. Families may be stigmatised or vilified for having a child with albinism and mothers are often left to bring up multiple children on their own. ${ }^{7}$ Imafidon ${ }^{8}$ has argued that people with albinism are considered both physically and ontologically different in Black African communities, as less than a human being. As such, people (especially children) with albinism are targeted in attacks to harvest body parts for use in ritual medicine and good luck charms. ${ }^{9}$ While persons with albinism may be considered a threat while alive, they are regarded as highly potent for ritual purposes when dead. ${ }^{8}$

\section{Explanations}

A recent scoping review highlights the multiple cultural and spiritual meanings that run alongside biomedical explanations attached to albinism. ${ }^{10}$ The umbrella terms 'witchcraft and sorcery' encompass beliefs and practices around supernatural powers ${ }^{11}$ that are integral to daily living in many regions ${ }^{12}$ :

In Uganda, the belief in witchcraft and 'black' magic is very strong ... evoking fear ... Very often people attribute death, diseases or any misfortune to witchcraft ... People hate or react violently to anybody suspected of using occult powers to harm or destroy. ${ }^{13}$

Witchcraft cannot be understood within binary dimensions such as good and evil-these practices and beliefs do not always lead to harm ${ }^{11}$ and can coexist with primary affiliations to world religions of Christianity and Islam. ${ }^{14}$

\section{Birth stories}

Stories of children's early experiences are important in children's growing sense of self and as a way of introducing them to their space in wider family communities. ${ }^{15}$ It is also important for women, as recounting birth stories allow the opportunity to share significant events, fears and concerns. ${ }^{16}$ The birth stories of children with albinism, in a context where there are strong beliefs in witchcraft, have not previously been explored.

\section{Research questions}

The analysis here is derived from a larger study across both Uganda and Tanzania that explored the impact of stigma and fear on education and life opportunities for people with albinism. We interrogated the Ugandan interview data to answer the following questions relating to those in attendance at the birth of a baby with albinism or, for those with albinism, who had been told the stories by their parents:

1. What were their birth stories, including reactions to the birth?

2. How was the birth of a child with albinism explained?

\section{Theoretical framework}

Imafidon ${ }^{17}$ has argued cogently that it is possible to talk about an African philosophy because of a shared understanding across the continent of a broad African understanding of personhood. The study was located within this
Afrocentric worldview. Working in partnership with local albinism advocates was essential to these reconstructions and interpretations, so participants knew and trusted the local researchers and as interviews were conducted in vernacular languages.

\section{METHODS \\ Setting}

The study was undertaken in the Busoga subregion (kingdom) in the eastern part of Uganda, around Lake Victoria, with Jinja as the industrial and economic hub. Most of Busoga is very rural and marked by chronic poverty, with heavy reliance on fishing, subsistence farming and roadside trade. Christian and Islamic religions are mainstream, but parallel African beliefs and practices inform rites at birth, marriage and death. Almost 800 persons with albinism are registered with the local association, Source of the Nile Union of Persons with Albinism (SNUPA). SNUPA's strong advocacy roots, government connections and wide networks along with a keenness to increase their evidence base made Busoga an ideal setting for conducting this research. There is scant information about albinism in the region and SNUPA is at the forefront of working with child protection and human rights organisations to debunk myths and persuade the government to take action.

\section{Study design and coproduction}

This study is a secondary analysis of qualitative data based on interviews and focus groups undertaken during 2017. Full details of the primary study are described elsewhere. ${ }^{18}$ A team of four local, Lusoga-speaking data collectors, with extensive experience in sensitive interviewing, undertook all data collection. The study adhered to Consolidated Criteria for Reporting Qualitative research guidance. The research was fully coproduced with people with albinism and their supporters from inception through to completion. SNUPA were essential partners, supported by the charity Advantage Africa.

\section{Study population, sampling and recruitment}

Participants were recruited through albinism groups in the Busoga subregion, through SNUPA's networks and by word of mouth in order to expand sample selection as much as possible. ${ }^{19}$ Seventy-three participants were recruited to eight sharing circles $(n=56)$ and individual interviews $(n=17)$. Sharing circles ${ }^{18}$ took place in local community spaces such as classrooms or under trees. Participants were self-selecting and included parents of children with albinism, people with albinism and a range of other interested parties, including TBAs, nurses or midwives and teachers.

\section{Data collection}

One-to-one interviews were conducted in a personcentred interviewing style. In the sharing circles, individuals took it in turn to tell their stories while the rest of the 
group listened respectfully. ${ }^{18}$ Interviews were conducted in the local language (Lusonga), recorded, translated into English and transcribed simultaneously by the interviewing team.

\section{Data analysis}

Discussion was held between the Ugandan and the UK researchers to check the parameters of the analysis. The analytic meetings were held in Jinja face-to-face in August 2018 and followed up by WhatsApp and email discussions. Data analysis followed an emergent and inductive analytic coding process. To enhance trustworthiness of the study, two researchers (JT, PL) undertook the analysis independently then met to agree coding trees and emergent themes. Two more analysts (CB-J, PO) 'sense' checked the themes and helped refine them. Analytic discussions informed the final interpretations and narrative.

\section{Patient and public involvement}

The SNUPA team included people with albinism, disabled people and Ugandan volunteers. SNUPA was central from inception, including developing the research questions and design, undertaking data collection and assisting in the analysis. People with albinism were recruited through SNUPA's networks and were invited to a stakeholder event to discuss and refine the findings at the end of the study. Educational and advocacy materials were distributed to all participants and the findings used by both SNUPA and their partner non-governmental organisation (NGO) Advantage Africa.

\section{RESULTS}

In total 46 informants gave separate accounts of birth stories from the wider sample, including reactions to the birth of a child with albinism and the explanation proffered for the phenomenon. There were three dominant, although overlapping themes: (1) reactions to the birth of a child with albinism; (2) spiritual beliefs, including those related to witchcraft, religion and animal familiars; (3) retribution and blame.

\section{Reactions: initial shock leading to gradual acceptance}

Mostly there was acceptance and support from the mother at the birth of a baby with albinism, but some participants reported maternal rejection and a lack of care at birth, for example, a young woman with albinism said:

I think my mom wanted me to die ... she aborted the following pregnancy saying she didn't want to give birth to another child like me.

However, initial shock often gave way to gradual acceptance.

It was a big shock to my parents, giving birth to a pale child. In fact, they feared, but with time they strengthened themselves. (man, 20s).
Immediate reactions to the birth included expressions of shock by immediate family members.

My husband's relatives started complaining, "What has she produced"? Some said I produced misfortunes. (woman, 20s)

Reactions from villagers and community members reinforced the sense of fear and rejection, but there was also curiosity about the birth of a child with albinism. People wanted to see with their own eyes.

... many people came to see what I have produced and they had a shock .... to find out that it was an albino child. (woman, 30s)

Mom told me, when people heard she has given birth to something not a human being but something .... she said she had never seen a person living with albinism. So she was also scared because most people were coming and seeing which kind of thing she has given birth to. (woman, 40s)

In the community after my birth most of their (parent's) friends distanced themselves .... People my Dad did business with, they stopped fishing with him. Even some relatives of my mum stopped coming to our family and stopped inviting her (with me) to visit them. (man, 20s)

However, these reactions were sometimes countered by courageous answers where mothers asserted their acceptance of the child:

When it comes to places like hospitals where woman gather, your fellow woman will have to ask you "do you breast feed even that child who is albino"? With confidence I answer her, that yes, I must breastfeed, after all it is my baby. (woman 30s)

People who came to see me scared me a lot; asking me why I gave birth to such a child; but I kept on telling them that it's only God who knows .... (woman 40s)

A woman with albinism recounts the general acceptance by both her parents and the community at her birth, attributing this to God's will:

When I was born, my parents didn't take it in bad faith and on the community, most of the children were my friends ... That's the child that God just gives you and he is a person like any other. (woman, 20s)

Another young woman with albinism suggests her family's understanding of albinism genetics was essential:

Fortunately ... I was born from literate parents who very well knew about albinism. They are both teachers but having medical personnel in their family; they well knew about albinism ... My great grandmother had albinism. Actually, I was named after her. .... they told us that these are genes that are inherited. So I was accepted. (woman, 40s) 
Unusually, one man thought his wife may have given birth to a baby with albinism due to his friendship with a man with albinism, an explanation that others in his community seemed to accept:

I thought my closeness with [friend] could have contributed to my wife producing a child with albinism ... When I took the child home, everyone confirmed that it was because of my closeness with [friend]. (man, 40s)

Occasionally the birth was not only accepted, but positively welcomed:

People were surprised to see an albino and gathered, they were very many at the hospital. They didn't abuse him. They only gave him gifts, some gave him money. (woman 50s)

However this was a more unusual occurrence, not expressed by the majority.

The role of the community in helping parents accept their child came through strongly:

I am told that when my mother gave birth of me, she told my father and grandmother that she has delivered but it is an albino, they disliked the message ... but the community members advised them [to] accept whatever God gave them. (man, teens)

A man with albinism recounts what he had heard about the community response to his birth, indicating acceptance in a community with previous experience of albinism:

they said "these children existed in the family long ago". At home they love me a lot. The community also love me. (man, 40s)

Reactions from birth attendants (doctors, nurses and TBAs) were particularly interesting. Some reinforced the fear and shock.

When I was producing that child, the nurse saw the child coming out and shouted, "What's this lady producing", I almost ran off the bed but decided to be strong. (woman, 30s)

Positive and explanatory information at birth and soon after was seen as extremely helpful and supportive.

[The midwife] comforted me that she knows other children who are like mine and that I should have no fear at all. (man 30s)

When the husband came to pick us from the hospital, he was called by the nurses for counselling and he started caring and supporting the child. (woman, 20s)

After getting him, I took him to hospital, the doctors told me the child has no problem but his genes brought that colour. (man, 40s)
Reactions to the birth of a baby with albinism were evocatively described by the participants, mostly referring to initial shock, humiliation and maternal disbelief. The birth was often described in terms of immediate rejection by the family and community, but in time for many this was replaced by a gradual acceptance. Most heartening were those stories where mothers courageously challenged negative reactions.

\section{Spiritual beliefs}

Our analysis unearthed over 50 accounts of beliefs about albinism associated with supernatural powers and witchcraft.

The family members lamented; "The child [mother] has brought a ghost", how can you leave town and bring a ghost to us.... Even the parent of the boy [father] ran away. (man, 50s)

Usually each village has a shrine where traditional healers centre their work and where villagers can make sacrificial offerings to their ancestors and other spirits.

There are some traditional beliefs that if a person with albinism passes next to African traditional shrine; the shrines can't function that day. They believe that persons with albinism have super spiritual powers which are stronger than the ghosts in the shrines. (man, $30 \mathrm{~s})$

Many people started saying "you see, she had gone to meet fellow albinos to get spiritual power to give birth" so there are many false beliefs attached to us by the community members. (man, 40s)

Although there was fear of the ancestral spirits, they were not always seen as malevolent.

... it was from the ancestral powers, spirits that made my Mom and Dad manage to give birth to me. (man, $20 \mathrm{~s})$.

Perceptions and explanations for the birth were often negative, with stories about spiritual beings or power that could cause harm or were a curse.

I produced her, many people started to talk about my family that I have produced [a] demon (Mujjini) and they hated my home. (man, 30s)

There were parallel, often conflicting beliefs in some communities.

Actually I was the first person to be born with albinism in the community ... some people thought it was from demonic powers, others thought God's arrangement. So worlds were colliding. (man, 50s)

Mainstream religious beliefs were strong and belief that a child with albinism was a gift from God, promoted a positive welcome.

My husband was supportive and always said my child was a gift from God. (woman, 30s) 
When we got him, we didn't lament because we knew it was God's making. (woman, 20s)

Others may have turned to religion as a way of coping with their conditions.

For me when I grew up I accepted in God and I knew that I was born by God's grace who knew my coming on earth. (man, 40s)

A particularly strong feature of the narratives was concerned with animal familiars, where snakes, leopards and other creatures were associated with the birth.

I thought I was giving birth to a snake. My husband was supportive but his relatives were hard on me. (woman, 40s)

Later they gave birth to me, they produced [gave birth to] me together with a leopard. They actually didn't produce me with a leopard but when Mom gave birth to me, the leopard used to come and sleep near our house. They told me it came every morning until my umbilical cord fell off. (man, 30s)

Also those children are born/accompanied with some animals ... [although] I know they're children just like others and I have never seen an animal at their birth. (woman, 30s)

Although participants described spirits, ghosts, demons, sorcery and witchcraft, with many references to superstition, some of the accounts countered this by describing having a baby with albinism as a gift from God.

\section{Blame and retribution}

The general reaction to the birth was one of blame and accusation as to how a baby so different in appearance from the rest of the community, could be born. Almost uniformly it was seen as the woman's fault, usually based on the belief that she had been unfaithful.

My Dad thought that maybe my Mom wasn't faithful to him that may be she went outside and conceived it from outside. (man, 30s)

I used to trust my wife but many people came to me saying that may be your wife committed adultery with another man. (man, 40s)

Even a grandmother was complicit in the blame:

In fact they rose against her thinking that maybe she might have gone out with a white man ... I also asked myself maybe she might have committed adultery. (woman, 60s)

Other reasons were proffered, still generally attributing blame to the mother.

They thought that may be my mother laughed at an albino somewhere in a certain society; it was God punishing her because she laughed .... Others thought they did something bad and God punished them. (man, 30s)
Men usually say that if you remain with the lady after producing a child with albinism, she could sacrifice you; you no longer have money ... men are advised to run from the family. (man, 40s)

As a consequence, women could be abandoned, chased from home and village.

The next morning he told his son to chase me .... He told them, "I didn't call you for anything else, but that one should leave my home. If she wants, let her go with her husband but she won't breastfeed that child in my home". (woman, 50s)

Although less common, there were accounts where men stayed with the woman and offered their support.

Friends to my husband told him "how dare do you stay with such a woman?, why don't you send her away?", but he would say "why to send her away and for what reason? She is my wife who produced my child". (woman, 40s)

Overwhelmingly initial reactions to the birth of a baby with albinism were negative, seeking to blame someone or something to account for this birth. Numerous causes were proffered, with accounts invariably pointed to a gendered attribution of blame and frequent abandonment of women.

\section{DISCUSSION}

The birth stories of people with albinism recorded in Busoga, Uganda were powerful, evocative, emotive and diverse. In contrast to an earlier study in South Africa showing initial maternal emotional upset and delayed attachment, followed over time by increasing acceptance $^{20}$ this Ugandan study included examples of early acceptance by mothers, although fatalistic. Initial reactions by family and community members to the birth were invariably those of shock, and in some cases TBAs reacted similarly, with women chiefly targeted as the miscreants responsible for the unusual birth. Explanations largely revolved around supernatural beliefs although some offered genetic reasons. Despite many African communities viewing albinism as a social and cultural abnormality, not to be welcomed, ${ }^{8}$ we found many stories of gradual acceptance of people with albinism. The focus on maternal 'fault' is largely linked to gender roles in Uganda, where patriarchy is the norm. ${ }^{21}$ Studies in other sub-Saharan countries have been similarly challenged by patriarchal attitudes and cultural taboos (eg, intimate partner violence in Zimbabwe ${ }^{22}$; HIV in South Africa ${ }^{23}$ ).

There has long been acknowledgement that cultural beliefs and norms around pregnancy practices have a powerful role in maternal health. ${ }^{24}$ Where birth attendants in this study were able to offer factual information about why a child had been born with albinism, this had a clear supportive and comforting impact on both mothers and fathers, to the extent that fathers especially could begin to 
accept the child. Although participants did not distinguish between a nurse, midwife, TBA or doctor as the birth attendant(s), the reactions of whoever helped with the birth were paramount. Kromberg and Manga ${ }^{25}$ stress the importance of all those attendant at the birth, or consulted after the birth (such as traditional healers) being well informed, so that appropriate counselling can be offered. Information based on genetics offers an effective alternative explanation to counter potentially damaging beliefs based on superstition, ${ }^{26}$ although it is unlikely to completely displace such deep rooted beliefs. All family members can benefit from specific genetic counselling services as has been reported in South Africa. ${ }^{27}$ Women in Uganda have reported reluctance to seek formal postnatal care ${ }^{28}$ and there are scarce opportunities for this in any case, thus the information provided at birth is crucial. Educational programmes and locally relevant information may help protect babies born with albinism and their mothers from abandonment and exclusion. ${ }^{29} 30$

Results of our study support previous work indicating that negative community reactions and attitudes impact on the social and mental well-being of the whole family, which can lead to rejection by and detachment from the community, whereas positive reactions were supportive at the crucial time when the parents were coming to terms with the birth of a baby with albinism. ${ }^{31}$ Our findings resonate with previous analyses highlighting the key role of grandmothers in African communities where group rather than individual decision-making prevails. ${ }^{31}$ Elders hold positions of great respect and grandmothers in particular can sway opinions regarding causal factors of a physiological condition, offering support and influencing the wider community. ${ }^{32}$

Many of the varied explanations offered in our study to account for this 'unknown' phenomenon ${ }^{33}$ focused on the supernatural. There are numerous accounts of people with albinism being known as ghosts (eg, see references ${ }^{34-36}$ ). While inspired by pale features, the terminology and understanding around ghosts is more complex than colour alone and is much feared. Kromberg ${ }^{31}$ has suggested that those with albinism in Africa may be seen as spirits (or the reincarnation of spirits) as they are 'white' whereas 'real' people in African societies are black and this may be linked to the sighting of animal familiars also. Our findings in Uganda are supported by investigations of the impact on the family of the birth of a baby with albinism in South Africa, where genetic explanations resided alongside superstition. ${ }^{20}$ Transmission or acquisition of clinical conditions as a result of supernatural powers has been similarly found in other studies in Uganda. ${ }^{37} 38$

Evidence from Africa over the last few hundred years has shown no sign that witchcraft narratives are losing any plausibility. ${ }^{39}$ For people with albinism, the perception of being in a 'magical' world, capable of doing good or evil, leads to a life of ambiguity. ${ }^{34} 40$ Within some African communities, those who lack the expected features of personhood (eg, by forms of disability, mental ill health, albinism) are denied the intrinsic worth of being a person. ${ }^{8}$ This can lead to an 'intersubjective' experience where persons with albinism navigate social stigma and violence. ${ }^{41}$

In some countries government and NGOs provide targeted interventions for people with albinism (mobile clinics, free surgery, education and advocacy), but provision is patchy and evidence of effectiveness unknown. ${ }^{10}$ Innovative public awareness interventions in neighbouring Tanzania have led to more positivity about albinism $^{42}$ as knowledge in the hands of religious and community leaders can shift an entire village's thinking. ${ }^{43}$ Such interventions need to be holistic and interactionist, rooted in local values and beliefs. ${ }^{44}$

A strength of this qualitative study is that it provides hitherto unreported birth stories and the reactions and explanations surrounding them. To that end, it has generated new knowledge in terms of understandings about albinism in Uganda. Until now, such insights have remained within the spheres of local communities. The sample size was unusually large for a qualitative study, which gives us confidence that a range of experiences have been captured. However, there were some challenges. Although the unique context of the Busoga subregion provides important insights as already stated, we recognise that knowledge and practices are contextual and that this limits generalisability.

\section{CONCLUSIONS}

Lack of understanding and misunderstandings about the nature of albinism support the ingrained stigma, prejudice and discrimination experienced by families after the birth of baby with albinism. Genetic accounts offer an alternative interpretation, helping to counter the myriad alternate explanations that surround the condition. In collectivist African communities all members of the community need to be informed, so that babies born with albinism, where the stakes are so high, are more readily accepted and valued. ${ }^{17}$

\section{Twitter Julie Taylor @bulawayojulie}

Acknowledgements We take this opportunity to thank the very many participants who came forward to share their experiences, insights and beliefs about albinism. Many thanks to Faruk Kiiza and Shafira Nabaggala from SNUPA who assisted with interviews, transcriptions and cultural interpretation.

Contributors PL led the study, P0 and FK were responsible for recruitment and the qualitative data generation, supported by JB and PL. JT, PL and CB-J undertook the secondary analysis. Interpretations of culture and context were provided by PO and FK. All authors contributed to the manuscript and read and approved the final version.

Funding This research was supported by FIRAH—Fondation Internationale de la Recherche Appliqué, grant number: FIRAH code AP2014-47. URL to their website (http://www.firah.org/, www.firah.org).

Competing interests None declared.

Patient and public involvement Patients and/or the public were involved in the design, or conduct, or reporting, or dissemination plans of this research. Refer to the Methods section for further details.

Patient consent for publication Not required.

Ethics approval Ethical approval was granted by Coventry University Research Ethics Committee and by the Minister for Disabled Persons, Jinja, Uganda as per local in-country protocol at the time of data collection. All participants gave both written and verbal informed consent. Although participants wanted to be 
identified to give voice to their stories, as a research team we are mindful of the current context of violence and danger towards people with albinism and have not identified their names or exact locations.

Provenance and peer review Not commissioned; externally peer reviewed.

Data availability statement Data are available on reasonable request to researchers who meet the criteria for access to confidential data from FIRAH International Foundation of Applied Disability Research: http://www.firah.org/index. php?option=com_content\&view=article\&id=30\&ltemid=95\&lang=en. Address: 14 rue de la Tombe Issoire -75014 Paris - France. Phone: +33 (0)1 431219 21. Email: contact@firah.org.

Open access This is an open access article distributed in accordance with the Creative Commons Attribution Non Commercial (CC BY-NC 4.0) license, which permits others to distribute, remix, adapt, build upon this work non-commercially, and license their derivative works on different terms, provided the original work is properly cited, appropriate credit is given, any changes made indicated, and the use is non-commercial. See: http://creativecommons.org/licenses/by-nc/4.0/.

ORCID iD

Julie Taylor http://orcid.org/0000-0002-7259-0906

\section{REFERENCES}

1 OECD. DAC list for ODA recipients, 2018. Available: https:// wwwoecdorg/dac/financing-sustainable-development/developmentfinance-standards/DAC List ODA Recipients2018to2020_flows Enpdf [Accessed 4th Nov 2018]

2 Kawuma A. Trained midwives a game changer for women and families in Uganda, 2016. Available: http://wwwswemfase/campaign/ trained-midwives-a-game-changer-for-women-and-families-inuganda/ [Accessed 04 Nov 2018].

3 Uganda Bureau of Statistics. Uganda demographic and health survey 2016, 2018. Available: https://dhsprogramcom/pubs/pdf/FR333/ FR333pdf [Accessed 14 Nov 2018].

4 Marçon CR, Maia M. Albinism: epidemiology, genetics, cutaneous characterization, psychosocial factors. An Bras Dermatol 2019;94:503-20.

5 Lewis Ret al. Oculocutaneous Albinism Type 2. In: Adam M, Ardinger H, Pagon R, eds. GeneReviews ${ }^{\circledR}$ [online]. Seattle, WA: University of Washington, Seattle, 2012. https://www.ncbi.nlm.nih.gov/books/ NBK1232/

6 Lund P, Roberts R. Prevalence of Albinism: Current Population Genetics Studies and Directions for Future Research: Large Scale Surveys and Censuses in Zimbabwe, Namibia and Tanzania. In: Kromberg J, Manga P, eds. Albinism in Africa. San Diego: Elsevier, 2018. : 82-100p.

7 Franklin A, Lund P, Bradbury-Jones C, et al. Children with albinism in African regions: their rights to 'being' and 'doing'. BMC Int Health Hum Rights 2018;18:2.

8 Imafidon E. Some epistemological isssues in the othering of persons with albinism in Africa. In: Imafidon E, ed. Handbook of African philosophy of difference. Geneva: Springer Nature, 2019: 1-18.

9 Under the same sun. reported attacks of persons with albinism, 2018. Available: https://www.underthesamesun.com/sites/default/ files/Attacks\%20of\%20PWA\%20-\%201\%20page_0.pdf [Accessed 05 Feb 2018].

10 Reimer-Kirkham S, Astle B, Ero I, et al. Albinism, spiritual and cultura practices, and implications for health, healthcare, and human rights: a scoping review. Disabil Soc 2019;34:747-74.

11 Millbank J, Vogl A. Adjudicating fear of witchcraft claims in refugee law. J Law Soc 2018;45:370-97.

12 Ashforth A. On living in a world with witches: Everyday epistemology and spiritual insecurity in a modern African city. In: Moore H, Sanders T, eds. Magical interpretations, material realities: modernity, witchcraft and the occult in Postcolonial Africa. Abingdon: Routledge, 2001.

13 Igwe L. Witchcraft and death in Uganda. Sahara reporters, 2013. Available: http://saharareporters.com/2013/04/10/witchcraft-and-deathuganda-by\%C2\%A0leo-igwe\%C2\%A0 [Accessed 26 Oct 2018].

14 Centre PR. Tolerance and tension: Islam and Christianity in sub-Saharan Africa. Washington: Pew Forum on Religion in Public Life, 2010.

15 Reese E. Conceptions of self in mother-child birth stories. JNLH 1996:6:23-38.

16 Callister LC. Making meaning: Women's birth narratives. Journal of Obstetric, Gynecological \& Neonatal Nursing 2006;33:505-18.

17 Imafidon E. Intrinsic versus earned worth in African conception of personhood. In: Imafidon E, ed. Handbook of African philosophy of difference. Geneva: Springer Nature, 2019: 1-18.
18 Bradbury-Jones C, Ogik P, Betts J, et al. Beliefs about people with albinism in Uganda: a qualitative study using the Common-Sense model. PLoS One 2018;13:e0205774.

19 Ndejjo R, Mukama T, Kiguli J, et al. Knowledge, facilitators and barriers to cervical cancer screening among women in Uganda: a qualitative study. BMJ Open 2017;7:e016282.

20 Kromberg JG, Zwane EM, Jenkins T. The response of black mothers to the birth of an albino infant. Am J Dis Child 1987;141:911-6.

21 Lundgren R, Burgess S, Chantelois $\mathrm{H}$, et al. Processing gender: lived experiences of reproducing and transforming gender norms over the life course of young people in northern Uganda. Cult Health Sex 2019:21:387-403.

22 Shamu S, Abrahams N, Temmerman M, et al. Opportunities and obstacles to screening pregnant women for intimate partner violence during antenatal care in Zimbabwe. Cult Health Sex 2013;15:511-24.

23 Abrahams N, Jewkes R. Managing and resisting stigma: a qualitative study among people living with HIV in South Africa. J Int AIDS Soc 2012;15:17330.

24 Turinawe EB, Rwemisisi JT, Musinguzi LK, et al. Traditional birth attendants (TBAs) as potential agents in promoting male involvement in maternity preparedness: insights from a rural community in Uganda. Reprod Health 2016;13:24.

25 Kromberg J, Manga P. Summary and Conclusion. In: Kromberg J, Manga P, eds. Albinism in Africa. San Diego: Elsevier, 2018: 310-25.

26 Lund PM. Oculocutaneous albinism in southern Africa: population structure, health and genetic care. Ann Hum Biol 2005;32:168-73.

27 Kromberg J. Genetic counseling and albinism. In: Kromberg $\mathrm{J}$, Manga P, eds. Albinism in Africa. San Diego: Elsevier, 2018. : 203-33p.

28 Sacks E, Masvawure TB, Atuyambe LM, et al. Postnatal care experiences and barriers to care utilization for Home- and FacilityDelivered newborns in Uganda and Zambia. Matern Child Health $J$ 2017;21:599-606.

29 Ojilere A, Saleh MM. Violation of dignity and life: challenges and prospects for women and girls with albinism in sub-Saharan Africa. $J$ Hum Rights Soc Work 2019;4:147-55.

30 Advantage Africa, SNUPA. We are human too [online], 2017. Available: https://wwwadvantageafricaorg/file/we-are-human-too-pdf [Accessed 18th Dec 2018].

31 Kromberg J. Psychosocial and cultural aspects of albinism. In: Kromberg J, Manga P, eds. Albinism in Africa. San Diego: Elsevier, 2018: 172-99.

32 Penn C, Watermeyer J, MacDonald C, et al. Grandmothers as gems of genetic wisdom: exploring South African traditional beliefs about the causes of childhood genetic disorders. J Genet Couns 2010;19:9-21.

33 Wan N. 'Orange in a World of Apples': The voices of albinism. Disabil Soc 2003;18:277-96.

34 Baker C, Lund P, Nyathi R, et al. The myths surrounding people with albinism in South Africa and Zimbabwe. Journal of African Cultural Studies 2010;22:169-81.

35 Brocco G. Labeling albinism: language and discourse surrounding people with albinism in Tanzania. Disabil Soc 2015;30:1143-57.

36 International Bar Association. Waiting to disappear': International and Regional Standards for the Protection and Promotion of the Human Rights of Persons with Albinism, 2017. Available: bit.ly/2qlk643 [Accessed 10 May 2017].

37 Dhabangi A, Idro R, John CC, et al. Community perceptions of paediatric severe anaemia in Uganda. PLoS One 2019;14:e0209476.

38 Nnko S, Bukenya D, Kavishe BB, et al. Chronic diseases in north-west Tanzania and southern Uganda. public perceptions of terminologies, aetiologies, symptoms and preferred management. PLoS One 2015;10:e0142194.

39 Witchcraft AA. Justice and human rights in Africa: cases from Malawi. African Studies Review 2015;58:5-38.

40 Taylor J, Bradbury-Jones C, Lund P. Witchcraft-related abuse and murder of children with albinism in Sub-Saharan Africa: a conceptual review. Child Abuse Review 2019;28:13-26.

41 Brocco G. Albinism, stigma, subjectivity and global-local discourses in Tanzania. Anthropol Med 2016;23:229-43.

42 Standing Voice. Science, Art, Community. Building Understanding of Albinism in Tanzania. Evaluation Report [online], 2017. Available: http://standingvoice-devs3amazonawscom/ c2b729c6ed5f06b2b4d0efbb7c50cf91pdf [Accessed 03 Sep 2018].

43 Docking M, mortality M. Uganda: can midwives make a difference? Women \& Birth Supplement: ACM2015 Oral Presentations 2015;28S:12.

44 Lund PM, Gaigher R. A health intervention programme for children with albinism at a special school in South Africa. Health Educ Res 2002;17:365-72. 